
TRIO vsk. 10 nro 1 - Lectiones praecursoriae: Olli Pyylampi 86-91

OLLI PYYLAMPI

\section{Agogiikka ja rekisteröiminen esittäjän keinovaroina saksalaisessa urkumusiikissa.}

Lectio praecursoria

Olli Pyylammen taiteellinen tohtorintutkinto tarkastettiin 16.11.2019 Musiikkitalon Organo-salissa Helsingissä. Jatkotutkinnon aihe oli "Agogiikka esittäjän keinovarana saksalaisessa urkumusiikissa". Kirjallisen työn nimi oli Rekisteröinnin taito. Tapausesimerkki urkurin äänikertavalintojen perusteista saksalaisromanttisessa ohjelmistossa. Tarkastustilaisuuden valvojana toimi MuT Päivi Järviö. Lausunnon tutkinnon taiteellisesta osuudesta antoi lautakunnan puheenjohtaja MuT Kati Hämäläinen. Lausunnon kirjallisesta työstä antoivat MuT Tuomas Mali ja MuT Matti Oikarinen.

Musiikkiesitykset lection aikana:

Italialaiset urut n. 1750:

Girolamo Frescobaldi (1583-1643): Canzona Quarta

Verschueren-urut 1994:

Nicolaus Bruhns (1665-1697): Praeludium in $G$

Johann Cristoph Oley (1738-1789): Du, o schönes Weltgebäude

Felix Mendelssohn Bartholdy (1809-1847): Andante D-Dur

Forster \& Andrews -urut 1892:

Gustav Merkel (1827-1885): Adagio im freien Styl op. 35

Franz Liszt (1811-1886): Präludium und Fuge über $B-A-C-H$

Taiteellisiin jatko-opintoihin pyrkiminen sai alkunsa seuraavista kysymyksistä: Mitä voisin tehdä paremmin, ettei soittoani kutsuttaisi hieman suoraviivaiseksi? Kuinka vapaasti agogiikkaa oikein pitäisi käsitellä soitettaessa? Miten asian voisi toteuttaa mahdollisimman tyylinmukaisesti?

Opintojeni otsikoksi muotoutui ”Agogiikka esittäjän keinovarana saksalaisessa 
urkumusiikissa.” Käytän termiä agogiikka sen kattavuuden ja kohtuullisen selvän merkityksen vuoksi, vaikka itse termi onkin vakiintunut käyttöön vasta 1900-luvulla. Tarkoitan agogiikalla ensisijaisesti tempon, mutta myös nuottien kestojen ja rytmien hienovaraista muuntelua.

Aihetta oli välttämätöntä rajata. Otinkin tutkimuksen kohteeksi vain saksalaisen kielialueen urkumusiikin. Aikakauden valitsin melko laajaksi, 1600-luvun lopulta aina 1800-luvun jälkipuoliskolle. Jakson alkupäähän liittyy urkumusiikissa pohjoissaksalainen stylus fantasticus -tyyli, jonka halusin ehdottomasti mukaan opintoihin. Jakson loppupään rajasin siten, että niin kutsutun uussaksalaisen koulukunnan musiikki tulisi mukaan tutkimukseen, mutta musiikinteoreetikko Hugo Riemannin vaikutukset, eli myöhäisromantiikan musiikki, jäisi pääosin pois. Myöhäisromanttisen musiikin esittämiskäytäntöjä on jo valmiiksi tutkittu paljon, ja esimerkiksi minun saamani musiikkiopistokoulutus ja monet 1900-luvulla vakiintuneet käytännöt perustuvat juuri Riemannin ajatteluun.

Tiedollisena tavoitteenani oli selvittää agogisia käytäntöjä ja niiden muuttumista barokista täysromantiikkaan saakka. Taidollisena eli taiteellisena tavoitteena oli näiden tietojen avulla kehittää omaa agogista ilmaisuani mahdollisimman tyylinmukaiseksi, hienovaraiseksi ja luontevaksi osaksi soittoani. Halusin myös löytää soitettavaksi keskeistä ohjelmistoa huomattavasti tuntemattomampaa musiikkia. Lähdemateriaaliksi määrittelin sävellysten ja niiden esipuheiden lisäksi muun muassa urku- ja pianokoulujulkaisut, säveltäjien muut kirjoitukset sekä musiikkiteoreetikoiden kirjoitukset. Suunnittelin opinnäytekonserttien sarjan siten, että musiikki eteni konsertista toiseen kronologisessa järjestyksessä. Näin voisin parhaiten seurata agogisen ilmaisun kehitystä.

\section{ITALIALAINEN TYYLI POHJOISSAKSALAISESSA BAROKKIMUSIIKISSA}

Ensimmäinen opinnäytekonserttini, "Pohjoissaksalainen Stylus fantasticus ja sen italialaiset juuret" sisälsi pohjoissaksalaista barokkimusiikkia. Sen tyylilliset jäljet johtavat saksalaisten ja italialaisten muusikoiden välisen kanssakäymisen vuoksi 1600-luvun Italiaan. Siellä muun muassa Claudio Monteverdin ja Girolamo Frescobaldin musiikki poikkesi merkittävästi aiemmasta tyylistä, muun muassa väljien äänenkuljetussääntöjen ja tasaisesta tahdinlyönnistä vapaamman esittämisensä puolesta. Esitinkin konsertissani vuorotellen Frescobaldin ja saksalaisten säveltäjien musiikkia ja pyrin näin etsimään ja osoittamaan tyylillistä yhteyttä.

Konsertissani käsiteltyä stylus fantasticusta voi pitää tuon vapaamman tyylin toisena, saksalaisena kehitysvaiheena, jonka huipensivat kosketinsoitinteoksissa muun muassa Dietrich Buxtehude ja Nicolaus Bruhns. Myös Johann Sebastian Bachin musiikissa on vielä paljon vaikutteita tästä tyylistä. Buxtehuden ja Bruhnsin teoksis- 
TRIO vsk. 10 nro 1 - Lectiones praecursoriae: Olli Pyylampi 86-91

sa vapaat fantasiajaksot, sekä ankarat, tasaiseen tactukseen perustuvat kontrapunktiset jaksot vuorottelevat.

Tätä vapaata tyyliä kuvaa Johann Mattheson hieman myöhemmin, vuonna 1739, seuraavasti:

Tämä on kaikkein vapain tyyli säveltää, laulaa ja soittaa, mitä voi kuvitella. Ensin tulee yksi idea sitten toinen. Mikään ei ole sidottu sanoihin tai melodiaan, vaan ainoastaan harmoniaan, joten laulaja tai soittaja voi esitellä taitojaan. Kaikenlaiset epätavalliset kehittelyt, nerokkaat käänteet ja koristelut tuodaan esille ilman metriikan ja sävellajin tarkkailua riippumatta siitä, mitä nuottiin on kirjoitettu. Välillä nopeasti, välillä epäröiden, välillä yksiäänisesti, välillä moniäänisesti, välillä myöhässä iskulta, mutta ei vailla tarkoitusta miellyttää, yllättää ja ällistyttää.

Niin säveltäjän kuin esittäjänkin vapaus lienee siis fantasiajaksoissa suuri. Kokonaan eri asia on, miten tämä toteutetaan hyvällä maulla.

Itseäni kiinnosti lisäksi, voisivatko Frescobaldin antamat esittämisohjeet toimia ohjeina myös pohjoissaksalaisessa fantasiatyylissä. Ainakin ohje pysähtymisestä nopean kuvion viimeisellä äänellä sen nuottiarvosta riippumatta tuntui sopivan myös saksalaiseen musiikkiin ja toi siihen totutusta poikkeavaa jännitettä.

\section{Johann Sebastian Bachin JäLKeinen aika}

Toinen opinnäytekonsertti koostui Johann Sebastian Bachin musiikista sekä etenkin 1700-luvun loppupuolen ja 1800-luvun alun musiikista. Bachin osalta mielenkiintoni esittämisessä kohdistui lähinnä siihen, missä märin vanhemman pohjoissaksalaisen tyylin esittämiskäytäntöä voisi soveltaa vielä Bachinkin preludeissa, fantasioissa ja toccatoissa, ja millaisia vapauksia niissä voisin tyylikkäästi ottaa. Muutenhan Bachin musiikin esittämistä on tutkittu paljon, ja kyse on paljolti tasaiseen tahdinlyöntiin ja tahtihierarkiaan perustuvasta kenraalibassomusiikista, jossa vapaudet otetaan lähinnä rytmikuvioiden ja muiden yksityiskohtien esittämisen tasolla.

Bachin jälkeistä aikaa urkumusiikissa, aina 1800-luvun alkupuolelle saakka, pidetään taantumuksellisena aikana, jolloin urkumusiikki ja urkurit eivät olleet suuressa suosiossa. Ajatellaanpa vaikka, miten vähän tunnetut klassismin ajan säveltäjät, kuten Haydn, Mozart ja Beethoven, ovat säveltäneet urkumusiikkia. Taitavia urkureita ja urkumusiikin säveltäjiä kyllä oli edelleen - etenkin Berliinissä, jossa Bachin musiikkiakin pidettiin arvossa vielä pitkään hänen jälkeensä. Monessa muussa paikassa se kuitenkin unohdettiin nopeasti vanhanaikaisena ja vaikeana niin soittaa kuin ymmärtääkin.

Ohjeita Bachin jälkeisen musiikin agogiikkaan löytyi niukasti, jos ollenkaan. Monia muita esittämisen aspekteja kuten artikulaatiota kyllä käsitellään runsaasti. Ainoa löytämäni mielenkiintoinen maininta oli ohje rubatosta Daniel Gottlob Tür- 
kin pianokoulusta vuodelta 1789. Siinä ohjeistetaan ottamaan vapauksia tasaisen säestyksen päällä olevan melodian käsittelyssä.

Valmistautuessani tuleviin konsertteihini löysin kuitenkin kirjallisuudesta mainintoja siitä, miten monet urkurit edelleen 1800-luvun alkupuolella soittivat vanhanaikaisesti, esimerkiksi tahtihierarkiaa korostaen. Saatoin siis vetää sen löyhän johtopäätöksen, että ainakin pääasiallisesti 1700-luvun loppupuolen ja aivan 1800-luvun alun urkumusiikin esittäminen on edelleen ollut metrisesti melko tasaista.

\section{КOHTI VAPAAMPAA AgOGIIKKAA}

Kolmannen opinnäytekonsertin, "Mendelssohnin matkassa Euroopassa”, omistin 1800-luvun alkupuolen mielestäni tärkeimmän saksalaisen urkusäveltäjän, jo omana aikanaan hyvin kuuluisan Felix Mendelssohnin musiikille. Hän oli valtavan kiinnostunut uruista ja urkumusiikista ja alkoi elvyttää urkumusiikkia jälleen suurten musiikinlajien joukkoon säveltämällä itse merkittävän urkutuotannon ja esittämällä sitä itsekin. Tyylillisesti hänen musiikkinsa nojautuu vahvasti perinteeseen, mutta tässä historian vaiheessa on jo siirrytty kenraalibassosta enemmän melodiajohtoiseen musiikkiin.

Mendelssohnin urkujensoitosta on luettavissa runsaasti aikalaisten kuvauksia. Niissä toistuvat samat määritelmät: Mendelssohn soitti melko nopeasti, aina selkeästi, otti vapauksia erityisesti omassa musiikissaan ja soitti hyvin poeettisesti. Viimeksi mainittu määritelmä tarkoittanee aiempaa vapaampaa agogiikkaa.

Kapellimestarina hän vaati soittajilta harjoituksissa tarkkaa tempossa pysymistä, mutta saattoikin konserteissa improvisoida yllättäviä kiihdytyksiä ja hidastuksia. Toisaalta Mendelssohnin oppilas Hans van Bülow raportoi, miten Mendelssohnin musiikkia tulisi soittaa tarkassa tempossa ja välttää sellaisia hidastuksia, joita ei ole merkitty nuotteihin. Hänen mukaansa Robert Schumannin musiikissa voi käyttää paljon enemmän tempon muuntelua kuin Mendelssohnin musiikissa.

Merkittävä pianopedagogi Carl Czerny opettaa pianokoulussaan vuodelta 1839 seikkaperäisesti kiihdytysten ja etenkin hidastusten käyttöä musiikin muotoilussa. Hän mainitsee myös, että liioittelua tulee välttää ja hidastuksia käytetään paljon enemmän kuin kiihdytyksiä. Lisäksi hänen mukaansa fuugat tulee aina soittaa tarkassa tempossa.

Ohjeita etsiessäni kohtasin toisilleen vastakkaisiakin käsityksiä. Selvältä vaikuttaa kuitenkin, että Mendelssohnin ja hänen aikalaistensa musiikissa tulisi käyttää ainakin jonkinlaista agogista muotoilua ja vapautta. On myös ilmeistä, että urkureilla uudet käytännöt ja muodit ovat tulleet käyttöön myöhemmin kuin pianistien keskuudessa. Von Bülow raportoi, miten urkurit, jotka ovat hyviä pianisteja, soittavat urkuja paljon mielenkiintoisemmin kuin pelkät urkurit. Tämänkin huomion oletan tarkoittavan erityisesti musiikin agogista muotoilua. 
TRIO vsk. 10 nro 1 - Lectiones praecursoriae: Olli Pyylampi 86-91

\section{REKISTERÖIMISEN HAASTEET URKURIN TYÖSSÄ}

Neljäs konsertti sisälsi niin kutsuttujen klassistien, eli vahvasti perinteeseen nojaavien 1800-luvun puolivälin ja jälkipuolen romantikkojen musiikkia. Tämän konsertin valmistelussa en löytänyt juurikaan uutta tietoa agogiikkaan liittyen. Koska musiikin tyyli oli samansuuntaista Mendelssohnin musiikin kanssa, jatkoin erityisesti omien taitojeni kehittämistä ja hiomista käyttäen hyväksi aiemmin löytämiäni ohjeita. Tässä vaiheessa opintoja rohkeampi agoginen muotoilu alkoikin vähitellen tuntua itselle luontevalta soittotavalta.

Neljännessä opinnäytekonsertissa huomioni kiinnittyi erityisen vahvasti myös rekisteröimiseen. Soitin konsertin Espoon tuomiokirkon aivan uusilla uruilla, jotka olivat saaneet vahvasti vaikutteita saksalaisen urkujenrakentajan, Friedrich Ladegastin tyylistä. Olin samana syksynä ennen konserttia päässyt tutustumaan myös kaksiin aitoihin Ladegast-urkuihin. Koska Espoon urut soivat silloisen tietämykseni perusteella hieman toisella tavalla kuin Ladegast-urut, käytin Espoossa paljon aikaa rekisteröintien miettimiseen ja pyrin houkuttelemaan uruista esiin minun tuntemaani Ladegast-sointia.

Tästä aihepiiristä syntyi tutkintoni kirjallinen työ, jossa selvitän kyseistä konserttia tapausesimerkkinä käyttäen, mihin kaikkeen rekisteröimistyöskentelyni todella perustuu. Työ osoittaa, että perusteet ovat ennen muuta historiallisten urkujen tuntemisessa sekä rekisteröimistaitojen ja sointikorvan kehittämisessä muiden urkureiden rekisteröintiavustajana.

Kirjallisella työllä halusin myös kasvattaa yleistä tietoisuutta rekisteröimisestä hyvin olennaisena urkurin taiteellisen toiminnan osana. Urkurinhan tulee suunnitella rekisteröinnit kuhunkin teokseen ja kullekin uruille aina erikseen, kuten olen tehnyt myös lectioni musiikkiosuutta varten.

\section{IRTI MENNEISYYDEN KAHLEISTA}

Viimeisessä, viidennessä konsertissa ohjelmisto koostui niin ikään täysromantiikan musiikista, mutta tällä kertaa esillä olivat säveltäjät, jotka halusivat uudistaa musiikillista ilmaisua niin sävellyksellisesti kuin esittämiskäytännöllisestikin.

Uussaksalainen koulukunta, perustajanaan Franz Liszt, halusi vapauttaa musiikin menneisyyden kahleista. Tässä tarkoituksessa he muun muassa suhtautuivat paljon aiempaa vapaammin sekä sävellysten muotoon että temponkäsittelyyn. Carl Czernyn lausunto oppilaansa Lisztin pianonsoitosta kuvaa agogiikan runsautta:"Hänen soitossaan hyvin tiheästi esiintyvä tempo rubato on niin hyvin laskelmoitua, että hän pysyy ymmärrettävänä jokaiselle kuulijalle, aivan kuten erinomainen puhuja.” Lienee selvää, että tässä musiikissa runsaahko agogiikan käyttö onkin tyylinmukaista. On kuitenkin huomattava, että edelleenkään ei ole kyse aivan Riemannin ajatusten 
mukaisista, pitkistä fraaseista ja niiden muotoilusta.

Konserttini sävellyksistä sekä Julius Reubken suuri sonaatti, että etenkin Lisztin Preludi ja fuuga ovat nykyään todella ladattuja tietyillä esittämisen konventioilla. Lisztin teosta soitetaan hyvin runsaalla agogiikalla ja nopeasti, vaikka partituuri ei anna läheskään kaikkeen tähän ohjeita. Myös Reubken ohjelmallista sonaattia soitetaan usein äärimmäisen nopeasti.

Tutkin huolellisesti Lisztin teoksesta myös sen varhais- ja pianoversioiden partituurit. Niissä esittämisohjeita ja tempomerkintöjä oli viimeistä urkuversiota enemmän tai ne olivat hieman toisenlaisia, ja nämä merkinnät vaikuttivat ikään kuin oikeuttavan monet niistä agogisista konventioista, joita teoksessa nykyään yleensä kuulee.

Sen sijaan tempojen osalta pidän tärkeänä omakohtaista soittokokemusta molempien teosten kantaesityspaikan, Merseburgin linnankirkon Ladegast-uruista sekä mielikuvaa kirkon suuresta akustiikasta. Kokemukseni mukaan sekä tämän suuren soittimen koneisto, että kirkon akustiikka viittaavat siihen, että tempot eivät ainakaan kantaesityksessä ole voineet olla valtavan nopeita. Soittaminen totuttua hitaammin on musiikillisesti jopa nopeaa soittoa vaativampaa, mutta kehittää valtavasti agogiikan hallintakykyjä.

Viidennen opinnäytekonsertin kohdalla koin, että agogiikan käyttö useilla eri tavoilla, sävellyksestä ja tyylistä riippuen, sekä soittotavan muuttaminen vaikkapa tilanteen, olosuhteiden ja mielialan mukaan, oli vihdoin sisäistynyt paremmin osaksi muusikkouttani. Agogiikan käyttö on erittäin subjektiivinen ja hienovarainen asia, johon jokainen muusikko joutuu muodostamaan oman suhteensa, kukin omalla tavallaan. 